\title{
PERILAKU VERBAL WANITA DALAM INTERAKSI SOSIAL DI PUSAT- PUSAT PERBELANJAAN DI DAERAH ISTIMEWA YOGYAKARTA
}

\author{
oleh Zamzani, Tadkiroatun Musfiroh, dan Yayuk Eny Rahayu \\ FBS Universitas Negeri Yogyakarta
}

\begin{abstract}
This article is about a study aimed at describing women's verbal behavior in social interaction at shopping centers at the phonological, lexical, structural, and pragmatic levels and the factors influencing it.

The results of the study can briefly be stated as follows. First, their pronunciation tends to exhibit (a) high tones, (b) the occurrence of lengthening, and (c) a volume varying between loud and low. The factors acting as the background are (a) the organs of articulation, (b) cultural factors, (c) situational contexts, and (d) functions of utterances. Second, the vocabulary used is partly honorific in nature, chosen in the course of respecting their partners in the interaction, especially in the use of salutations. Third, the structure of the language used tends to undergo (a) deletions of certain parts considered already commonly understood by the communication participants, (b) contractions in the pronunciation of certain words, and (c) occurrences of salutations at the end of utterances. The factors acting as the background are (a) the setting of the interaction, which involves spoken language used face-to-face so that the communication participants are in the same situational context, (b) the level of formality of the interaction, (c) the level of the participants' intimacy, and (d) honorific factors characteristic to women. Fourth, pragmatically implicatures tend to be used at certain times. A factor acting as the background is a culture of a high context and it functions as an indicator of the speaker's social status or level.
\end{abstract}

Keywords: verbal behavior, social interaction, pronunciation, vocabulary, structure, pragmatic

\section{A. PENDAhUluan}

Manusia dalam hidupnya selalu menjalin komunikasi dengan sesamanya, dan berinteraksi untuk berbagai kepentingan. Dalam berinteraksi digunakan alat yang berupa bahasa verbal dan nonverbal. Dalam peristiwa komunikasi itu, apa yang dinyatakan dalam tindak tutur (speech act) memiliki makna lokusi (locutionary act) dan seringkali bernilai tindakan ilokusi tertentu (illocutionary act), serta memiliki efekbagi petuturnya yang berupa tindak perlokusi (perlocutionary act). Dalam peristiwa komunikasi tersebut kaidah yang rumit digunakan untuk mengungkapkan act sehingga untuk menangkap hakikat act dalam setiap tuturan diperlukan kaidah yang rumit pula. Kerumitan tersebut tidak membuat orang dalam komunikasi terkendala, melainkan justru merasakan kenikmatan selama dalam kontkes dan budaya yang sama.

Tindak tutur memilki bentuk yang sangat beragam, terdependensi oleh konteks yang melingkupinya. Tindak tutur pria dan wanita cenderung berbeda. Oleh karenanya tuturan di antara keduanya pun berbeda, termasuk dalam tuturan untuk meminta dan mengekspesikan diri. Demikian pula tuturan anak-anak dan orang dewasa pun tidak sama. 
Meski demikian, hamper tidak ada manusia normal yang mengalamiu kendala dalam memahami tuturan sesamanya, selama konteks tuturnya yang lekat tidak dilepaskan.

Tuturan wanita secara universal memiliki ciri-ciri khas yang berbeda dari kaum laki-laki dalam berinteraksi verbal. Wanita cenderung menyukai kestandaran dan keformalan untuk menyelamatkan muka mitra bicara dan memelihara kehormatan dirinya. Sejumlah penelitian yang dilakukan ahli Barat menguatkan dugaan tersebut. Selain itu, tuturan wanita dipenuhi dengan bentuk pertanyaan tag (question tag), bentuk-bentuk eufimisme, tekanan-tekanan empatik, isian leksikal, dan ajektiva "kosong". Tuturan wanita juga mempunyai intonasi yang cenderung tinggi dan berisi banyak penyangatan (lihat juga Holmes, 1992:312-314; Edwards, 1995 : 201).

Wanita dalam perilaku linguistiknya dinilai lebih konservatif, bahkan sejak masa kanak-kanak. John Fischer (dalam Edwards, 1995 : 199-200). menemukan bahwa tuturan anak perempuan lebih taat asas daripada anak laki-laki. Riset di Detroit terhadap laki-laki dan perempuan dalam berbagai kelas sosial juga menunjukkan bahwa tuturan perempuan dari berbagai strata sosial lebih sedikit melakukan kenegasian ganda daripada laki-laki (negasi ganda merupakan bentuk yang tidak standar). Hal itu disebabkan kesadaran wanita akan status. Tuturan bagi wanita menunjukkan adanya status yang melekat pada diri seseorang Dengan kata lain, wanita berusaha memelihara status ketika berbicara.

Permasalahan jantina (gender) memang banyak dikaji, namun permasalahan yang menyangkut identitas kebahasaan wanita di Indonesia belum banyak dilakukan. Penelitian di Barat memang cukup marak, namun tentu ada beberapa kekhasan yang menyangkut bentuk kebahasaan dan topik yang ada dalam tuturan wanita Indonesia. Selain itu, Yogyakarta merupakan pusat budaya yang memiliki pranata sosial, termasuk di dalamnya strata sosial, yang masih stabil, dan dikategorikan sebagai masyarakat yang memiliki budaya konteks tinggi, bahkan mungkin tertinggi di Indonesia (lihat juga Nurkamto, 2001).

Kajian mengenai perilaku verbal wanita pernah dilakukan oleh tim peneliti ini (2005), khususnya perilaku verbal wanita di pasar tradisional, sehingga penelitian ini merupakan penelitian "lanjutan" dengan setting yang berbeda, yaitu di pusat perbelanjaan. Hal itu memang perlu dilakukan karena kajian mengenai perilaku verbal wanita dalam interaksi sosial yang dilakukan di pusat perbelanjaan di DIY belum pernah dilakukan. Kajian ini menjadi menarik untuk dilakukan karena para wanita yang berinteraksi sosial dalam setting di pusat perbelanjaan memiliki status atau kelas sosial yang berbeda dengan interaksi sosial yang berada di pusat perbelanjaan tradisional. Pusat-pusat perbelanjaan cenderung dikunjungi oleh wanita dan pria dari berbagai etnis. Selain itu, barangbarang yang dijual dan ditawarkan, system penawaran, dan pola interaksi tawar-menawar (bila terjadi) dipastikan berbda dengan interaksi serupa di pasar atau pusat perbelanjaan tradisonal. Untuk mendeskripsikan bagaimana ciri-ciri kebahasaan dan perilaku pragmatik wanita perlu dilakukan penelitian sehingga diperoleh deskripsi yang dapat dipertangungjawabkan perlu dilakukan.

Kajian ini diharapkan dapat mengungkap semua ciri-ciri perilaku verbal wanita dalam interaksi sosial di pusat perbelanjaan di DIY dalam berbagai tataran, sehingga tujuan penelitian adalah mendeskripsikan perilaku verbal wanita dalam interaksi sosial di pusat perbelanjaan di DIY (1) dalam tataran fonologi, (2) dalam tataran kata, (3 dalam tataran kalimat, (4) dalam tataran pragmatik, dan (5) latar belakang munculnya perilaku verbal wanita tersebut. Setting interaksi sosial tersebut meliputi pusat perbelanjaan Mal Maliobaro, dan Mal Galeria, Alfa, Indogrosir, dan Carrefour (Plaza Ambarukmo).

Untuk dapat mengungkapkan kelima butir tujuan tersebut digunakan ancangan kualitatif dengan mengedepankan (1) konteks natural, (2) peneliti sebagai instrumen (human 
instrument), (3) konsep diangkat dari empiri (induktif), (4) ketiadaan prakonsepsi, (5) aplikatif tentatif, dan (6) kriteria kepercayaan untuk menguji kredibilitas dilakukan dengan pengamatan berulang dan pengumpul data ganda (Moeloeng, 1995; Muhajir, 1991, Speadley, 1980, Strauss \& Corbin, 1990)

Kajian sosiolinguistik di Barat tentang bahasa wanita dari tahun 1959 hingga saat ini menunjukkan hasil yang konsisiten, yaitu tuturan wanita cenderung membawa "keprestisean" (Fischer, 1959; Labov, 1966; Wolfram, 1966, Trudgill, 1974; Labov, 2001). Sayangnya, penelitian itu belum banyak dilakukan secara intensif di Indonesia, khususnya di DIY.

\section{a. Bahasa Dilihat dari Jantina}

Dari sudut jantina terdapat perbedaan dalam beberapa hal (1) bentuk linguistik (Holmes, 1995:311), (2) fonologis (Holmes, 1995:164-165; Haas dalam Fasold, 1990: 8990; Wardhaugh, 1992: 314; Poedjosoedarmo, 2001: 112), (3) morfologis dan kosa kata (Ekka, 1972; Lakoof dalam Wardhaugh, 1986,305306;1992: 315-316) sehingga dijumpai seksis, (4) struktur (Holmes, 1995: 168-190), dan (5) pragmatik (Wardhaugh, 1992: 316) terutama dalam hal pilihan variasi bahasa, dan ( 6) paralingusitik, gerak, dan gesture (Wardhaugh, 1992: 317).

\section{b. Ciri-ciri Kebahasaan Wanita}

Bahasa wanita cenderung bermuatan gosip (gossip-laden), karup (corrupt) karena cenderung tidak langsung, tidak logis (illogical), eufemistis (Wardhaugh, 1992: 113). Selain itu, wanita cenderung menggunakan tanyaan tag, intonasi naik untuk deklaratif, selain pertanyaan, kata-kata penanda intensitas, bentuk yang sangat sopan dan mengindari kata vulgar; mengidentifikasi warna secara cermat, dan penuh empati (Wardhaugh, 1988: 303-307; 1992: 312-114; Holmes, 1995:312-2315; Edwards, 1995: 201). Variasi tuturan wanita cenderung mengarah pada variasi tuturan di atas tingkat kelas sosial komunitasnya (Chambers \& Trudgill, 1990: 92-95). c. Sebab-sebab Perilaku Linguistik Wanita

Latar belakang perilaku verbal wanita setidaknya ada empat fenomena, yaitu (1) kelas sosial dan status, (2) peran wanita dalam masyarakat, (3) status wanita, dan (4) fungsi tuturan.

Wanita cenderung menggunakan bahasa standar dan sopan untuk mempertegas status sosialnya. Selain itu, wanita yang berbahasa standar berasosiasi dengan status sosial yang tinggi karena wanita diseyogyakan berperilaku sopan; kesalahan perilaku pada maskulin cenderung ditoleransi, sedangkan wanita tidak demikian. Wanita dianggap subordinat sehingga harus berbuat sopan dan hati-hati. Wanita harus taat aturan, halus, tertata, dan menghindari bahasa yang berkesan "macho", bebas, maskulin, dan berkonotasi kuat (Lihat Trudgill, 1984, 167-168; Holmes, 1995: 171-176).

\section{B. PERILAKU VERBAL WANITA DALAM INTERAKSI SOSIAL DI PUSAT PERBELANJAAN}

\section{Perilaku Verbal Tataran Fonologi Wanita di Pusat Perbelanjaan di DIY}

Secara garis besar perilaku verbal wanita pada tataran fonologi dalam interaksi sosial di pusat perbelanjaan Daerah Istimewa Yogyakarta dapat dikategorikan menjadi tiga kelompok berdasarkan kriteria kepanjangan (length), tinggi nada suara, dan volume suara. Pertama, lafal yang cenderung terjadi pemanjangan bila dibanding dengan pelafalan yang normal, terutama terjadi pada tuturan "penjual" kepada pembeli. Kedua, nada suara cenderung lebih tinggi bila dibanding dengan suara pria. Ketiga, volume suara cenderung lebih keras pada tutran "penjual" dengan "penjual" daripada tuturan "penjual" kepada pembeli, atau wanita pembeli dengan kelauarganya atau temannya.

Pelafalan kata pada perilaku verbal wanita di pusat perbelanjaan Daerah Istimewa Yogyakarta yang menjadi lokasi penelitian ini terdapat kecenderungan terjadi pemanjangan pada peristiwa interaksi sosial tertentu. 
Peristiwa tertentu itu meliputi interaksi antara "penjual" dengan pembeli pada saat "penjual" menawarkan jasa atau menawarkan dagangannya, pada "penjual" dengan "penjual" saat melakukan pemanggilan dengan jarak yang agak jauh, pada saat "penjual" dan pembeli menyampaikan ucapan terima kasih. Pemanjangan lafal kata yang dominan terjkadi pada kata sapaan $\mathrm{Bu}$, Mbak dan hampir pada setiap tuturan terakhir. Hal itu memperoleh kesan santun dan tampak tidak tergesa-gesa.

Pemanjangan lafal yang terjadi pada saat "penjual" bertutur kepada pembeli mengesankan "pembeli" berperilaku santun dan menghormat karena tingkat hubungan yang berbeda dan susana "formal" muncul. Hal tersebut tampak sekali pada terjadinya cara bertutur saat berganti mitra tuturnya, dari sesama "penjual" dalam komunikasi yang terkesan akrab dan santai berpindah ke mitra tutur pembeli sehingga suasana terkesan berubah menjadi formal. Selain itu, saat "penjual" (SPG) menawarkan dagangan kepada pembeli juga terdapat kecenderungan adanya pemanjangan lafal yang memperoleh kesan "merayu" pembeli.

Kesan pemanjangan lafal terjadi pula pada penutur wanita yang tampaknya berlatar Jawa. Mungkin kesan pemanjangan tersebut terjadi karena pelafalan para penutur wanita dipusat perbelanjaan tersebut cenderung lambat atau pelan-pelan. Bahkan, terjadi pula sudah pelafalannya lambat masih dimunculkan beberapa lafal kata yang dipanjangkan. Selain itu, pemanjangan lafal kata terjadi pula wanita pada mitra interaksinya yang cenderung untuk memberikan kesan 'pemanjaan", "kemesraan" serta "keharmonian" pada mitra interaksinya atau pada orang lain yang ada disekitarnya.

Berikut ini disajikan salah contoh interaksi sosial yang di dalamnya terjadi pemanjangan lafal pada kata-kata tertentu. (Tanda titik tiga digunakan untuk menandai pemanjangan lafal kata yang di depannya.)

Peristiwa sosial ini terjadi di Malioboro Mall (McDonald's) dengan konteks sebagai berikut. Partisipan interaksi sosial terdiri atas A (pembeli, wanita, usia kira-kira 30 tahun, Jawa, tampilan modis terkesan modern), B (pembeli, wanita (anak A), usia kira-kira 5 tahun, Jawa, tampilan modis terkesan modern), dan $\mathrm{C}$ ("penjual" (pramuniaga counter), wanita, usia kira-kira 25 tahun, berseragam McDonald's, sederhana terkesan modern).

Seorang wanita (A) bersama anaknya (B) masuk ke McDonald's langsung mencari tempat duduk di sebelah barat dekat kaca, meletakkan belanjaan, lalu A menggendong B ke arah washtafel untuk mencuci tangan. Setelah selesai mereka menuju ke meja pemesanan dengan A menggandeng B. Terjadilah dialog sebagai berikut.

(1) $\mathrm{C}$ : Mari, Bu... mau pesan apa? (C melihat ke $\operatorname{arah} A$ dan B)

A: Paha Mbak dua, kentang satu, Ice cream satu. (berhenti sejenak, melihat B) Adik... mau apa sayang...?

B : Roti burger, Ma..., sama Ice cream .

C: Minumnya, Bu...? (sambil mengetik di mesin kassa)

A: Coca cola tanpa es, Mbak... (sambil melihat ke "penjual")

C: Sudah, Bu..? (sambil terus mengetik di mesin kassa). Semua nam delapan tuju ratus (melihat kea rah $\mathrm{A}$ ).

A: (Memberikan uang seratus ribuan) Ini, Mbak... (memandang "penjual")

C: (Menerima sambil berujar pelan) Ada tuju ratus, $\mathrm{Bu}$...? (memandang $\mathrm{A}$ )

A: Ada, Mbak (membuka tas, mengambil uang dari tas) Ini Mbak... (menyodorkan uang ke C)

$\mathrm{C}$ : Ini kembalinya, $\mathrm{Bu} . .$. (menaruh uang kembalian di atas nampan makanan). Makasih...

A : Sama-sama... (berjalan menuju kursi bersama-sama B) (Catatan lapangan II, 020506)

Dalam peristiwa interaksi di Malioboro Mall (tanggal 2 Mei 2006) yang ditunjukkan pada kutipan di atas tampak sekali bahwa untuk menuturkan kata sapaan $\mathrm{Bu}$, Mbak dan Adik 
cenderung terjadi pemanjangan lafal, dan pada kata sayang yang dimunculkan oleh A kepada B. Pemanjangan lafal kata sapaan $B u$ dan Mbak pada pemakaian di atas agaknya digunakan untuk mengekspresikan rasa santun dan hormat, pemanjangan lafal sapaan Dik untuk mengungkapkan rasa sayang dan pemanjaan A pada B. Hal itu dikuatkan pula dengan pengunaan kata sayang yang dituturkan dengan nada tertentu dan dilafalkan agak panjang juga.

Lafal lambat (bukan pemanjangan lafal) terjadi pada sebagian besar tuturan wanita yang berlatar etnis Jawa. Hal itu mengesankan bahwa wanita yang bertutur tersebut tidak tergesa-gesa, bahkan secara umum mengesankan pada konsep alon-alon waton klakon, 'biar lambat asal terlaksana' yang mungkin pula menjadi pandangan dunia penuturnya. Melakukan sesuatu itu tidak perlu tergesa-gesa, tetapi harus hati-hati, teliti, dan terselesaikan dengan baik. Hal itu tampak pada sebagian tuturan wanita yang berlatar etnis Jawa yang agaknya sejalan dengan temuan penelitian sejenis yang dilakukan oleh Zamzani, Tadkiroatun Musfirof, dan Prihadi (2004; 2005) khusus pada perilaku verbal wanita Jawa dalam interaksi sosial di pasar tradisional di DIY. Pola tuturan yang demikian itu, mungkin tidak saja merupakan kekhasan perilaku verbal wanita, tetapi justru menjadi kekhasan perilaku verbal penutur Jawa, pria dan wanita tanpa terkecuali. Orang lain di luar suku Jawa bisa jadi menganggapnya perilaku verbal orang Jawa begitu lamban, kurang trengginas, atau cekatan. Ya, perilaku verbal penutur Jawa memang dikenal lemah lembut.

Suara dari lafal wanita di pusat perbelanjaan Daerah Istimewa yang diteliti cenderung memiliki nada yang lebih tinggi bila dibanding dengan lafal pria. Hal tersebut mungkin disebabkan oleh organ artikulasi atau alat artikulasi yang khas pada wanita. Organ artikulasi yang khas pada wanita memberikan peluang menghasilkan nada yang tinggi tersebut. Kesan nada yang tinggi tersebut mungkin pula disebabkan oleh suara yang lebih kecil bila dibanding dengan suara pria. Justru suara yang kecil selama ini berasosiasi dengan suara wanita, dan suara yang besar berasosiasi dengan suara pria. Suara wanita yang besar ada pula yang meragukan kefeminanan wanita tersebut, sehingga ada yang menyebutnya bisek.

Volume suara lafal wanita di pusat perbelanjaan Daerah Istimewa yang diteliti cenderung lebih keras daripada lafal dalam tuturan yang normal muncul pada suasana yang khusus, yaitu saat sesama "penjual" berinteraksi dengan jarak yang agak jauh, misalnya melakukan kegiatan pengambilan barang dari rak yang tinggi. Selain itu, suara lafal keras dimuncul tidak hanya oleh wanita khusus di area permainan untuk anak-anak dan remaja. Sebaliknya, saat mereka "ngerumpi" volume suaranya lemah/ kecil sekali, berbisikbisik, nyaris tak terdengar oleh orang yang berada di sekitarnya, termasuk peneliti. Hal itu terjadi pula pada wanita sebagi pembeli saat bericara dengan "keluarga" atau temannya terutama saat akan memutuskan jadi atau tidaknya membeli suatu bara. Volume suara akan bergeser dari keras menjadi lebih lemah ketika berganti mitra iinteraksinya. Volume suara "penjual" cenderung melemah saat berkomunikasi dengan pembeli.

Volume suara pada saat berbicara pada wanita terkait dengan sopan santun. Wanita terhormat tidak dianjurkan berbicara dengan volume suara yang keras dalam suasana normal. Mungkin, kecenderungan munculnya volume suara keras yang terjadi dalam interaksi antara sesama "penjual" di pusat perbelanjaan diakibatkan oleh keperluan, bukan oleh suasana, sedangkan khusus di area permainan untuk anak-anak dan remaja pemunculan lafal keras diakibatkan oleh suasana yang gaduh. Volume suara yang melemah cenderung untuk menunjukkan rasa hormat "penjual" pada pembeli, atau karena ada faktor kerahasiaan terutama pada saat pembeli berintaraksi dengan sesame pembeli untuk membuat keputusan membeli atau tidak suatu dagangan atau belanjaan, atau saat "pembeli" ngrumpi. 


\section{Perilaku Verbal Tataran Kata Wanita di Pusat Perbelanjaan di DIY}

Penggunaan kosa kata dalam perilaku verbal wanita dalam interaksi sosial di pusat perbelanjaan Daerah Istimewa yang diteliti dapat dikelompokkan sebagai berikut. Pertama, kosa kata yang digunakan di pusat perbelanjaan di DIY sebagian besar kosa kata bahasa Jawa, yang diikuti atau digabung dengan kosa kata bahasa Indonesia. Kosa kata bahasa Jawa digunakan oleh wanita sebagai "penjual" saat berinteraksi dengan sesama "penjual" atau pembeli dengan pembeli. Namun, "penjual" dengan pembeli atau sebaliknya cenderung muncul kosa kata bahasa Indonesia karena mereka berbahasa Indonesia. "Penjual akan bergeser menggunakan kosa kata Jawa (berbahasa Jawa) pada saat pembeli memberikan respons dalam bahasa Jawa. Pengunaan kosa kata Jawa yang dominan sekali muncul pada pembeli pada 'penjual" di Indogrosir dan Alfa pada tanggal "tua", dan hal itu tidak terjadi di pusat perbelanjaan yang lain. Pada tanggal "muda" cenderung penggunaan kosa bahasa Indonesia lebih dominan. Kedua, sapaan bentuk hormat (honorifik) dari "penjual" cenderung muncul di pusat perbelanjaan yang diteliti.

Penggunaan kosa kata bahasa Jawa yang dominan di pusat perbelanjaan, khususnya pada interaksi "penjual" dengan "penjual" dan pembeli dengan pembeli (keluarga atau teman) memang dapat dimaklumi. Latar etnis Jawa sebagian besar "penjual" dan pembeli telah memungkinkan munculnya situasi interaksi yang demikian, termasuk dalam pemilihan kosa kata dan bahasa. Selain itu, kemunculan kosa kata dan bahasa Indonesia di pusat perbelanjaan ini juga dapat dimaklumi karena penjual dan pembeli serta pengunjung pusat perbelanjaan tersebut cukup homogen dilihat dari etnis dan penguasaan bahasa. Pembeli dan "penjual" yang berlatar etnis Jawa dalam kehidupan sehari-hari memang cenderung berbahasa Jawa. Sedikit sekali penutur yang di rumah menggunakan bahasa Indonesia dalam berkomunikasi (untuk menyatakan tidak ada), kecuali berkomunikasi dalam situasi formal seperti di kantor atau di sekolah.

Pemunculan kosa kata bahasa Indonesia pada tanggal "muda" dan pemunculan kosa kata Jawa pada tanggal "tua" pada para pembeli agaknya juga dapat dimakllumi. Pada tanggal "muda" untuk para pegawai bersama keluargannya berbelanja di pusat perbelanjaan itu. Para pegawai tersebut terdapat kecenderungan berkomunikasi dengan bahasa Indonesia di pusat perbelanjaan. Selain itu, pada tanggal "muda" bagi pelajar dan mahasiswa, yaitu saat beru saja mereka dapat kiriman dari orang tuanya terdapat kecenderungan mereka yang berasal dari luar Yogyakarta tersebut berbelanja di pusat perbelanjaan. Tentu saja mereka berbahasa Indonesia dalam berinteraksi sosial. Sebaliknya, pada tanggal "tua" pegawai dan pelajar serta mahasiswa sedikit sekali yang berbelanja di pusat perbelanjaan, dan yang datang ke pusat perbelanjaan (khususnya pusat grosir Alfa dan Indogrosir). Mereka pada umumnya pedagang untuk membeli dagangan. Mereka cenderung berkomunikasi dalam bahasa Jawa, termasuk dengan para "penjual", dan mereka sudah saling mengenalnya secara baik dan akrab.

Penggunaan kosa kata bentuk hormat atau honorifik dilakukan oleh "penjual" kepada pembeli atau pengunjung di pusat perbelanjaan di DIY yang diteliti. Bentuk sapaan yang dipilih yang berasosiasi dengan masyarakat "desa" dihindari dalam perilaku verbal wanita. Penggunaan sapaan Mbok dan Yu yang di kota Yogyakarta berkonotasi dengan pembantu, meski di desa tidak demikian, tidak ditemui sama sekali. Sapaan yang ditemukan dalam interaksi sosial yang dimunculkan oleh penutur wanita cenderung yang bernilai hormat dan modern. Kosa kata sapaan yang ditemukan dalam penelitian ini adalah Mas, Mbak, Bu, Mama, Papa, Dik, dan Jeng.

Contoh perilaku verbal dalam interaksi sosial berikut menunjukkan penggunaan bahasa sekali gus kosa kata yang dipilihnya.

Interaksi sosial ini terjadi di Mall Galeria Yogyakarta, di salon, diobservasi pada 1 Mei 2006. Partisipan interaksi adalah A 
(penjual (capster salon), usia kira-kira 28 tahun, Jawa, sederhana, modern), B (penjual (capster salon), usia kira-kira 28 tahun, Jawa, sederhana, modern), C (pembeli (tamu), pria, usia kira-kira 30 tahun, sederhana, modern). Di ruang itu terdapat Pembeli (pelanggan) dan "penjual: (capster salon) yang lain. Mereka berbincangbincang, dengan interaksi sebagai berikut.

(2) A: (Sambil memijat-mijat kepala C) Piye perkembangan masalahmu?

B : (Sambil mengeringkan rambut pembeli/ pelanggan, bukan C) Embuh mbak, $r a$ takgagas.

A: Wis berapa bulan ta ra tok jupuk motormu? (Amenatap pada B)

B : Rong wulan ini, tapi biarlah aku juga bingung, mau ambil pakai apa?

A: Apa pinjam aku dulu. Ini ada kalau cuma sithik.

B: Gak sah, Mbak. Nanti juga ada jalan. Aku lagi minta sama Masku tak suruh ngutangi dulu. (sambil meletakkan pengering rambut, ia beralih berbicara pada C). Gimana, Mas, kurang kering ndak?

C: Cukup, Mbak. Makasih. (Catatan Lapangan I, 010506)

Kosa kata bahasa Jawa dan bahasa Indonesia digunakan secara bercampur dan secara bergantian pada interaksi sesama "penjual", yaitu dalam interaksi antara A dan B. Bahasa Indonesia digunakan oleh "penjual' kepada pembeli/pelanggan seperti yang telah dijelaskan di atas.

Penggunaan bentuk sapaan bentuk hormat sekaligus pilihan kata hormat (honorifik) dalam perilaku wanita mungkin terkait dengan kesadaran status, santun, subasita, dan prestise pada wanita Jawa seperti yang terdapat pada uraian teori di depan. Bahkan, untuk menunjukkan hal-hal tersebut bentuk yang bernuansa desa atau kampung dihilangkan, tidak dinyatakan dan hanya dimunculkan yang lebih bernilai tinggi dan terkesan modern. Kata sapaan yang digunakan Jeng pada peristiwa interaksi 3 di counter
Bucheri (Catatan lapangan II, 020506) meski berbau Jawa tetapi bernilai sosial yang tinggi. Potongan dialog tersebut sebagai berikut.

(3) A: Ini Bagus, Jeng?
B: Iya, Mbak. Cocok buat suku penjenengan.

Penggunaan Jeng tampak sekali untuk menghormat mitra interaksi, dan diberi respon dengan sapaan berkesan hormat Mbak yang dilengkapi dengan bentuk hormat (honorifik) suku penjenengan 'kaki kamu'.

Penggunaan leksikon dialek Jakarta (Betawi) juga muncul dalam perilaku verbal wanita dalam interaksi sosial di pusat perbelanjaan di DIY, dan boleh dikatakan cukup dominan. Leksikon yang digunakan adalah sih, dong, deh, doang, gak, dan kata gantu gue dan $l u$. Selain itu, penggunaan bentuk imbulan ngedan in sebagai pembentuk kata kerja bahasa Indonesia dialek Jakarta sering muncul. Berikut dikutipkan peristiwa interaksi sosial yang menggambarkan intensitas penggunaan leksikon bahasa Indonesia dialek Jakarta.

Partisipan interaksi A (pembeli, wanita, usia kira-kira 40 tahun, Jawa, sederhana, modern); B (pembeli (anak A), usia kira-kira 17 tahun, jawa, modis, modern); C1 ("penjual" (pelayan) wanita, usia kira-kira 25 tahun, Jawa, sedrhana, modern); C2 ("penjual" (pelayan) wanita, usia kira-kira 25 tahun, Jawa, sedrhana, modern). Lokasi interaksi sosial di Alfa counter buah dan sayuran.

(4) A: Eh... gimana tuh temanmu? Udah sembuh belum? (sambil memilih buah)

B: Tau tuh, Ma. Dia itu manja kalau sakit. Ya, gitu jadinya gak sembuh-sembuh. (sambil memilih, memijit-mijit jeruk yang berada di dekatnya)

A: Emangnya sakit apaan? Kok lama amat! (sambil melirik ke B)

B: Iya sih. Ma... beli anggur dong. Mumpung turun harga... (berjalan mendekati anggur) Mbak... tolong carikan plastik yang agak besar ya! (B beralih berbicara kepada $\mathrm{C} 1$ ) 


\section{Perilaku Verbal Tataran Struktur Wanita di Pusat Perbelanjaan di DIY}

Penggunaan struktur dalam perilaku verbal wanita dalam interaksi sosial berikut. Pertama, penghilangan (delisi) bagian tuturan yang tertentu yang dianggap telah dipahami oleh partisipan komunikasi. Kedua, pemunculan sapaan cenderung muncul pada akhir setiap penggalan tuturan. Ketiga, cenderung terjadi pemendekan lafal kata (kontraksi).

Penghilangan bagian tuturan cenderung terjadi pada perilaku verbal wanita dalam interaksi sosial di pusat perbelanjaan yang diteliti. Penghilangan bagian tuturan itu dilakukan khusus bagian yang dianggap telah menjadi "milik bersama" partisipan komunikasi. Bagian yang dihilangkan dapat berupa bentuk verba, dapat pula nomina. Pada peristiwa interaksi pada kutipan di atas telah menguatkan adanya kecenderungan menghilangkan bagian yang telah dianggap "milik bersama" tersebut. Berikut disajikan ulang penggalan interaksi sosial yang di dalamnya terdapat penghilangan unsur yang telang dipahami oleh partisipannya.

(5) C: Mari, Bu... mau pesan apa? (C melihat ke $\operatorname{arah} \mathrm{Adan} \mathrm{B}$ )

A: Paha Mbak dua, kentang satu, Ice cream satu. (berhenti sejenak, melihat B) Adik... mau apa sayang...?

Jika "Paha Mbak dua" mestinya "Saya pesan paha ayam kepada Mbak dua", dan sama sekali tidak menginformasikan atau pesan dua paha milik Mbak tersebut. Demikian pula "Adik... mau apa sayang...?' terdapat kata pesan yang tidak diungkapkan. Cantoh lain tidak perlu disajikan di sini karena hampir setiap interaksi terjadi penghilangan bagian tuturan. Hal tersebut agaknya memenuhi ciri bahasa lisan yang cenderung terjadi penghilangan bagian tertentu yang dianggap telah dipahami oleh partisipan komunikasi, dan didukung oleh konteksnya.

Pemunculan sapaan dalam perilaku verbal wanita dalam interaksi sosial di pusat perbelanjaan yang diteliti cenderung terdapat pada akhir penggalan tuturan. Penggunaan sapaan yang muncul pada awal penggalan tuturan sedikit sekali, dan muncul pada interaksi antarpenutur yang sudah saling mengenalnya. Berikut ini dikutipkan ulang catatan lapnagan II, 020506. (Deskripsi konteks dan partisipan interaksi tidak perlu disajikan lagi.)

(6) C: Mari, Bu... mau pesan apa? (C melihat kea rah Adan B)

A: Paha Mbak dua, kentang satu, Ice cream satu. (berhenti sejenak, melihat B) Adik... mau apa sayang...?

B : Roti burger, Ma..., sama Ice cream .

$\mathrm{C}$ : Minumnya, Bu...? (sambil mengetik di mesin kassa)

A : Coca cola tanpa es, Mbak... (sambil melihat ke "penjual")

C: Sudah, Bu..? (sambil terus mengetik di mesin kassa). Semua nam delapan tujuh ratus (melihat kearah A).

A: (Memberikan uang seratus ribuan) Ini, Mbak...(memandang "penjual")

$\mathrm{C}$ : (menerima sambil berujar pelan) Ada tuju ratus, $\mathrm{Bu}$...? (memandang $\mathrm{A}$ )

A: Ada, Mbak (membuka tas, mengambil uang dari tas) Ini Mbak... (menyodorkan uang ke C)

$\mathrm{C}$ : Ini kembalinya, $\mathrm{Bu} . .$. (menaruh uang kembalian di atas nampan makanan). Makasih...

A: Sama-sama... (berjalan menuju kursi bersama-sama B) (Catatan lapangan II, 020506)

Pemunculan sapaan sebanyak sepuluh kali dalam peristiwa interaksi tersebut, sembilan di antaranya berposisi akhir, dan hanya sekali pemuculan sapaan muncul pada awal, yaitu pada truturan "Adik... mau apa sayang...?". Kecenderungan kemunculan sapaan pada akhir penggal uturan tersebut terjadi pada peristiwa interaksi sosial yang lain (lihat catatan lapangan yang dilampirkan, dan kutipan yang lain di atas). Hal itu tentulah memperkuat adanya simpulan bahwa pemunculan sapaan pada perilaku verbal 
wanita dalam interaksi sosial di pusat perbelanjaan di DIY terdapat pada akhir penggalan tuturan. Mungkin sekali ini justru menjadi ciri-ciri khas struktur tuturan wanita yang di dalamnya memunculkan kata sapaan.

Bentuk sapaan dapat muncul pada awal tuturan selain muncul pada partisipan yang sudah saling mengenal, juga muncul saat sapaan tersebut berfungsi untuk memanggil (vokatif), seperti terjadi pada peristiwa interaksi yang terjadi antara "penjual" dengan "penjual" . Misalnya, tampak pada potongan interaksi sosial antara "penjual" dengan "penjual" berikut ini.

Partisipan interaksi A (pembeli, wanita, usia kira-kira 40 tahun, Jawa, sederhana, modern); B ("penjual" (pelayan) wanita, usia kira-kira 20 tahun, Jawa, sedrhana, modern); C ("penjual" (pelayan) pria, usia kira-kira 25 tahun, Jawa, sedrhana, modern). Lokasi interaksi sosial di Indogrosir counter perlengkapan bayi/anak-anak.

(7) A: Ada pilihan yang lain, Mbak...? (sambil melihat-lihat pampers yang dipajang di rak)

$\mathrm{B}$ : Bentar, Bu... (melihat ke $\mathrm{C}$ yang berada di tangga dan sedang melihatlihat kardus di atas rak-rak bagian atas) Mas Bud, Mas Bud, ambilkan yang itu! Softlove itu!

C: Yang ini? (Sambil memegang, dan mengamati kardus yang dimaksud.)

B : Itu, ada tulisannya Softlove gitu kok. Kanannya.

C: Awas tangkap. Jatuhkan saja ya! Ringan kok.

B: Ee.... Jangan, nanti rusak. (C membawa turun pelan-pelan dari atas)

(Catatan lapangan III, 060506)

Pada peristiwa interaksi tersebut jelas sekali bahwa Mas Bud yang di ulang tersebut lebih dominan pada fungsi vokatif dari pada menyapa. Dengan demikian, sebenarnya pemunculan bentuk sapaan sangat sedikit yang berada pada awal potongan tuturan. Ini merupakan kekhasan perilaku verbal wanita pada interaksi sosial di pusat perbelanjaan Daerah Istimewa Yogyakarta, sama dengan yang ditemukan pada penelitian sebelumnya mengenai perilaku verbal wanita Jawa pada interaksi sosial di pasar tradisional di DIY (Zamzani, Tadkiroatun Musfiroh, dan Prihadi, 2004; 2005).

Pemendekan lafal kata (kontraksi) sebagai gejala struktur kata bahasa lisan, khususnya pada situasi tidak formal terjadi pada perilaku verbal wanita dalam inteaksi sosial di pusat perbelanjaan DIY yang diteliti. Bentuk pemendekan itu terjadi pada kata-kata seperti membeli dilafalkan beli, bagaimana dilafalkan gimana, sebentar dilafalkan bentar, begitu dilafalkan gitu, terima kasih dilafalkan makasih.

Pemendekan lafal kata terjadi pada perilaku verbal wanita dalam interaksi sosial antara pembeli dengan pembeli (keluarga/ teman), "penjual" dengan "penjual" dan sedikit sekali terjadi dalam interaksi penjual dengan pembeli atau sebaliknya. Pemendekan lafal kata terjadi karena di antara partisipan sudah saling mengenal atau bahkan akrab hubungannya, serta suasana tidak formal. Pemendekan lafal kata "penjual" pada interaksi dengan pembeli terjadi pada saat pembicara tergesar-gesa. Dengan demiukia, faktor situasi, tingkat hubungan antarpartisipan, dan media yang digunakan dalam berinteraksi berperan sebagai penentu struktur kata yang digunakan oleh penutur.

\section{Perilaku Verbal Tataran Pragmatik Wanita di Pusat Perbelanjaan di DIY}

Perilaku verbal pada tataran pragmatik wanita dalam interaksi sosial di tiga pusat perbelanjaan Daerah Istimewa yang diteliti dapat dikelompokkan sebagai berikut. Pertama, bentuk tuturan pertanyaan sebenarnya secara pragmatik memiliki makna meminta atau menyuruh. Kedua, bertutur kepada seseorang dapat berfungsi sebagai informasi bagi orang lain (orang ketiga). Ketiga, bentuk implikatur cenderung digunakan untuk mengindikatorkan status sosial pembeli yang dilakukan oleh "penjual". Bentuk yang paralel antara tuturan 
dan maksud tidak perlu dibahas dalam penelitian ini karena hal itu sudah begitu lazim dijumpai.

Pada saat pembeli mengharapkan diambilkan barang pada "penjual", terdapat kecenderungan memunculkan dalam lagu tanya, meski pada beberapa peristiwa tutur tidak dimunculkan dalam bentuk pertanyaan. Pertanyaan tersebut secara pragmatik sebenarnya meminta pada "penjual" agar "penjual" mengambilkan barang yang diminta oleh pembeli. Hal itu dilakukan mungkin untuk memberikan kesan sopan pada "penjual", selain didukung oleh pilihan kata yang cenderung mengarah pada honorifik juga. Berikut ini disajikan potongan peristiwa tutur sebagai contoh. (Konteks dan partisipan tidak disajikan lagi, telah disajikan di atas.)

(8) A: Ada pilihan yang lain, Mbak...? (sambil melihat-lihat pampers yang dipajang di rak)

$\mathrm{B}$ : Bentar, $\mathrm{Bu} . .$. (melihat ke $\mathrm{C}$ yang berada di tangga dan sedang melihatlihat kardus di atas rak-rak bagian atas) Mas Bud, Mas Bud, ambilkan yang itu! Softlove itu!

$\mathrm{C}$ :

(Catatan lapangan III, 060506)

Tuturan yang dimunculkan oleh A kepada B sebenarnya bukan bertanya, melainkan agar diambilkan barang lain yang masih tersedia atau tersimpan. B memahami betul ekspresi A yang sebenarnya diminta untuk menyediakan barang lain sebagai pilihan, dan dipenuhinya dengan cara meminta kepada $\mathrm{C}$ untuk mengambilkan barang yang dimaksudkan. A berekspresi dalam bentuk implikatur kepada B, dan B memberikan penafsiran implikatur A secara tepat.

Tuturan yang diarahkan kepada seseorang dapat berfungsi sebagai informasi bagi orang lain, orang ketiga yang mendengar tuturan tersebut. Hal tersebut terjadi pada waktu seorang pembeli ditanya oleh "penjual", si pembeli justru berbicara dengan temannya. Pembicaraan pembeli dengan temannya tersebut justru dianggap oleh "penjual" menjadi jawaban atas pertanyaan yang diajukannya. Hal itu dapat dicontohkan berikut ini. Peristiwa seperti ini muncul pada lokasi di stand pameran atau promosi, baik yang ada di Indogrosir, Galeria, maupun di Malioboro Mall. Contoh tersebut dapat disajikan pada potongan interaksi berikut ini.

(9)

$\mathrm{A}$ : susunya $\mathrm{Bu}$. Ini mumpung promo.

B : Ha, itu kan yang.... Panteskan Jonetan pernah bilang gitu? (B sambil memperagakan kepada $\mathrm{C}$ tentang gigi yang panjang)

C: Ya memang, Ronaldo juga terlalu banyak minum susu itu). (Catatan Lapangan IV, 140506 Peristiwa Interaksi IIV)

Pada peristiwa inetarksi tersebut jawaban pertanyaan A dari B tidak diperoleh secara langsung, tetapi didasarkan pembicaraan $\mathrm{B}$ dengan $\mathrm{C}$ sebagai temannya. A tidak perlu lagi mengajukan pertanyaan ulang kepada $\mathrm{B}$, tetapi langsung menafsirkan jawabannya berdasarkan pembicaraan $\mathrm{B}$ dengan $\mathrm{C}$. Informasi untuk menolak seperti yang dilakukan oleh $\mathrm{B}$ dan $\mathrm{C}$ tersebut sering muncul, termasuk pada tawaran untuk pijat (refleksi) dengan alat elektronik yang marak di tawarkan di Indogrosir, Galeria, dan Malioboro Mall pada saat pengumpulan data ini dilaksanakan.

Bentuk implikatur cenderung digunakan untuk mengindikatorkan sosial pembeli yang dilakukan oleh "penjual" dengan menginterpretasikan penampilan pembeli. "Penjual" cenderung memberikan prasangka kepada pembeli melalui penampilan luarnya untuk menetapkan status sosial pembeli. Prasangka yang diberikan oleh "penjual" tersebut tentu saja dapat benar, dapat pula salah, baik under estimate maupun over estimate. Peristiwa tersebut sejalan dengan yang terdapat pada teori bahwa wanita memiliki kedasaran yang tinggi akan status sosial, termasuk dengan menunjukkan cara berbahasanya. Oleh karena itu, kecenderungan wanita melihat status sosial 
mitra interaksinya juga terjadi saat wanita berinteraksi atau berkomunikasi dengan orang lain. Orang lain tentu dituntut kearifannya untuk menafsirkan prilaku verbal wanita tersebut (termasuk perilaku verbal "penjual"). Wanita sebagai "penjual" tentu saja berharap bahwa implikaturnya tidak ditafsirkan secara negatif oleh pembeli, sehingga pembeli tidak tersinggung.

Berikut ini diberikan potongan interaksi yang muncul pada Catatan Lapangan I, 010506 peristiwa interaksi 8, yang berbeda sekali dengan peristiwa interaksi 7 dalam bidang yang sama, tetapi partisipan yang berbeda, bigitu pula dengan peristiwa interaksi 3 (untuk meyakinkan, lihat Catatan Lapangan I, 010506 pada lampiran). Partisipan interaksi sosial terdiri atas A (pembeli, laki-laki, kirakira 35 tahun, Jawa, sederhana), B (pembeli (perempuan 25 tahun, Jawa sederhana), dan C ("penjual" (pramuniaga counter), wanita, kirakira 25 tahun, luar Jawa, modern, glamor). Lokasi terjadinya interaksi di Galeria Mall, pameran stand Honda Jazz.

Sepasang suami istri menghampiri pameran mobil yang ada di lantai dasar Mall Galeria. Begitu memasuki area pameran suami istri terbut melihat-lihat mobil Honda yang sedang dipamerkan. Dengan teliti si laki-laki mengamati satu persatu bagian mobil Jazz yang sedang dipamerkan. Penampilan mereka sangat sederhana, tidak menunjukan status sosial menengah ke atas.

(10)A: Maaf, Mbak bisa minta brosurnya (sambil mendekati ke arah pelayan)

B: Yang Jazz Mas, daftar harganya sekalian ( menujuk ke arah mobil, sambil terus mengamati)

C: Ini pak... (tanpa melihat ke arah pembeli)

B: Makasih Mbak (terus pergi ke luar lokasi stand, tanpa dipersilakan mengisi buku tamu)

Dalam konteks yang demikian itu, para partisipan interaksi pembeli dan "penjual" harus membekali diri dengan kemampuan pragmatik atas ungkapan yang muncul dalam interaksi. Partisipan perlu memahami dan menguasai perilaku wanita dalam berinteraksi sosial yang cenderung tidak langsung (berimplikatur), mereka memiliki kesadaran status sosial dalam berinteraksi sehingga bahasanya cenderung teratur, dan berkecenderungan menfasirkan status sosial mitra interaksinya melalui ikon yang tampak secara eksplisit dari penampilan mitra interaksinya.

\section{Latar Belakang Perilaku Verbal Wanita di Pusat Perbelanjaan di DIY}

Perilaku verbal wanita dalam berinteraksi sosial di pusat perbelanjaan Daerah Istimewa Yogyakarta yang diteliti meungkin dilatarbelakangi oleh beberapa hal yang secara tidak langsung telah disajikan dalam empat butir pembahasan di atas. Secara garis besar faktor yang melatarbelakangi perilaku verbal wanita dalam berinteraksi sosial di pusat perbelanjaan dapat disajikan sebagai berikut.

Perilaku verbal wanita pada tataran fonologi dalam interaksi sosial di pusat perbelanjaan yang diteliti dilatarbelakangi oleh faktor latar kebudayaan (Jawa pada umumnya), alat artikulasi, dan lokasi atau setting komunikasi. Faktor kebudayaan terkait dengan kekhasan wanita yang cenderung berperilaku lemah lembut, santun, kesadaran status sosial yang tinggi, dan semua itu memiliki nilai pragmatis. Faktor alat artikulasi wanita cenderung menghasilkan suara yang lebih tinggi (bila dibanding dengan alat artikulasi pria) sehingga terkesan volumenya keras. Tempat di memberikan peluang untuk berbicara dengan volume yang lebih keras daripada suasana yang normal terutama pada saat suasana ramai, seperti di arena permainan elektronik. Suasana keformalan juga mempengaruhi volume suara yang dimunculkan oleh partisipan komunikasi. Volume suara yang terlalu keras saat berbicara dalam suasana formal dipandang sebagai bentuk tuturan yang kurang sopan. Faktor kepentingan juga mempengaruhi valume dan panjang pendek serta kecepatan tuturan. Untuk 
keperluan yang sifatnya "rahasia" atau privasi cenderung dilafalkan dengan volume yang lemah, diusahakan tidak dapat didengan oleh orang yang yang tidak terlibat dalam interaksi. Pemanjangan lafal kata-kata tertantu dilatarbelakangi oleh keinginan untuk bersikat santun, atau mengekspresikan kemanjaan.

Perilaku verbal wanita pada tataran kosa kata dalam interaksi sosial di pusat perbelanjaan yang diteliti dilatarbelakangi oleh kehendak penutur untuk berlaku sopan dan menghormat pada mitra komunikasi. Pilihan kata yang digunakan menggambarkan sikap penutur pada mitra tuturnya. Oleh karena itu, dapat dipahami bila kosa kata yang dikenakan pada mitra tutur dan sapaan yang digunakan bentuk hormat. Selain itu, digu-nakannya kosa kata Jawa yang dominan dalam interaksi dan dan kosa kata bahasa Indonesia dilatarbelakangi oleh komunitas penuturnya. Penutur di pusat perbelanjaan memang relatif heterogen, tetapi penutur yang berlatar etnis Jawa tetap dominan. Oleh karena itu, faktor heterogenitas komunitas interaksi memliki andil yang paling besar dalam penentuan pilihan kosa kata dan bahasa yang dipergunakannya.

Kecenderungan perilaku verbal wanita dengan menghilangkan atau tidak mengucapkan bagian tertentu dari suatu tuturan dilatarbelakangi oleh konteks yang telah mendukungnya. Bagian yang dihilangkan tersebut telah dipahami dan menjadi "milik bersama" partisipan komunikasi. Hal ini merupakan hal yang lazim dalam peristiwa interaksi lisan. Kontraksi kata dimunculkan oleh penutur di dalam interaksi sosial dilatarbelakangi oleh tingkat keformalan interaksi, dan situasai "hati" tergesa-gesa atau tidak. Sementara itu, pemunculan kata sapaan yang cenderung berada pada bagian akhir bagian tuturan mungkin dilatarbelakangi oleh faktor nilai kesopanan, dan ini merupakan kekhasan struktur verbal wanita dalam interaksi sosial di pusat perbelanjaan yang diteliti.

Perilaku verbal wanita dalam interaksi sosial di pusat perbelanjaan secara pragmatik dilatarbelakangi oleh kehendak untuk menyampaikan sesuatu secara tidak langsung, secara tersembunyi, berimplikatur, termasuk di dalamnya memberikan indikator status sosial diri dan mitra interaksinya. Hal itu agaknya sejalan dengan kebudayaan Jawa yang termasuk ke dalam kebudayaan konteks tinggi (hight context culture). Bahkan, bentuk implikatur yang dimunculkan dalam interaksi dapat digunakan untuk memberfikan informasi pada orang ketiga yang tidak terlibat di dalamnya.

\section{PENUTUP}

Perilaku verbal wanita pada tataran fonologi dalam interaksi sosial di lima pusat perbelanjaan Daerah Istimewa Yogyakarta dapat dikategorikan menjadi tiga kelompok berdasarkan kriteria kepanjangan (length), irama, nada sebagai gambaran dialek, dan volume suara. Pertama, lafal yang cenderung terjadi pemanjangan bila dibanding dengan pelafalan yang normal terjadi pada SPG saat menawarkan dagangannya pada pengunjung (pembeli). Kedua, irama, nada sebagai gambaran dialek yang dominan berupa variasi Betawi, dan Jawa. Ketiga, volume suara cenderung berganti-ganti, kadang keras atau lemah. Selain itu, kecepatan pelafalan juga bervariasi ada yang cepat dan ada yang lambat.

Penggunaan kosa kata dalam perilaku verbal wanita dalam interaksi sosial di pusat perbelanjaan Daerah Istimewa yang diteliti kosa kata bahasa Jawa dan Indonesia. Kosa kata bahasa Jawa banyak digunakan terutama terjadi pada saat tanggal-tanggal "tua", jauh dari hari "gajian", dengan pengunjung bukan "pegawai" sedikit yang menggunakan kosa kata bahasa Indonesia, tetapi pada tanggal "muda" terjadi kebalikan, lebih banyak digunakan bahasa Indonesia, atau setidaknya berimbang antara bahasa Jawa dan Indonesia.

Penggunaan struktur dalam perilaku verbal wanita dalam interaksi sosial dipusat perbelanjaan dapat disebutkan sebagai berikut. Pertama, penghilangan (delisi) bagian tuturan yang tertentu yang dianggap telah dipahami oleh partisipan komunikasi. Kedua, kontraksi kata terjadi pada pembiacara yang sudah saling 
mengenal dan akrab. Ketiga, pemunculan sapaan cenderung muncul pada akhir setiap penggalan tuturan, terutama dimunculkan oleh "penjual" pada pengunjung atau pembeli.

Perilaku verbal wanita pada tataran pragmatik dalam interaksi sosial di lima pusat perbelanjaan Daerah Istimewa yang diteliti dapat dikelompokkan sebagai berikut. Pertama, bentuk tuturan pertanyaan sebenarnya secara pragmatik memiliki makna meminta atau memerintah, bentuk pernyataan dapat memiliki makna meminta atau menyuruh. Kedua, bertutur kepada seseorang dapat berfungsi sebagai infor-masi bagi orang lain (orang ketiga). Ketiga, bentuk implikatur cenderung digunakan untuk mengindikatorkan status sosial diri dan mitra interaksinya.

Perilaku verbal wanita dalam interaksi sosial di pusat perbelanjaan yang diteliti dilatarbelakangi oleh faktor latar kebudayaan, usia, dan lokasi atau setting komunikasi. Faktor kebudayaan terkait dengan kekhasan wanita (terutama Jawa) yang cenderung berperilaku lemah lembut, santun, dan semua itu memiliki nilai pragmatis. Sebaliknya, dialek Betawi cenderung dilatarbelakangi oleh usia/pendidikan, karena lafal ini digunakan oleh wanita remaja dan anak-anak, sedikit sekali yang dimunculkan oleh wanita pada usia di atasnya. Pemanjangan lafal terjadi pada wanita SPG dalam upaya mempengaruhi pembeli. Demikian juga, pelambatan lafal dan mengecilnya volume terjadi saat "penjual" berkomunikasi dengan pembeli yang kemungkinannya dianggap lebih santun dan suasana lebih formal karena tingkat hubungan yang belum akrab, serta suara berbisik-bisik terjadi antara pembeli dengan pembeli (keluarga) saat menentukan atau memutuskan sesuatu, dan "penjual" dengan "penjual" saat berbicara yang agak rahasia atau sekedar "mengobrol".

Kehendak penutur untuk berlaku sopan dan menghormat pada mitra komunikasi melatarbelakangi pada pilihan kosa kata yang digunakan para wanita, serta untuk menggambarkan sikap penutur pada mitra tuturnya atau pada orang ketiga.
Kecenderungan perilaku verbal wanita Jawa menghilangkan atau tidak me-ngucapkan bagian tertentu dari suatu tuturan dilatarbelakangi oleh konteks yang telah mendukungnya, terutama bahasa lisan nonformal. Bagian yang dihilangkan tersebut telah dipahami dan menjadi "milik bersama" partisipan komunikasi. Hal ini merupakan hal yang lazim dalam peristiwa interaksi lisan. Pemunculan bentuk kontraksi dilatarbelakangi oleh tingkat keformalan, sedangkan pemunculan kata sapaan yang cenderung berada pada bagian akhir bagian tuturan mungkin dilatarbelakangi oleh faktor nilai kesopanan.

Perilaku verbal wanita dalam interaksi sosial di pusat perbelanjaan secara pragmatik dilatarbelakangi oleh kehendak untuk menyampaikan sesuatu secara tidak langsung, secara tersembunyi, berimplikatur. Hal itu agaknya sejalan dengan kebudayaan masyarakat Timur yang termasuk ke dalam kebudayaan konteks tinggi (hight context culture). Selain itu, bagi "penjual" perilaku berimplikatur itu diharapkan pem-beli tidak merasa dipaksa untuk membeli dagangan yang ditawarkan.

\section{DAFTAR PUSTAKA}

Chambers, J.K. \& Trudgill, Peter. 1990. Dialektologi. (Terj. Annuar Ayub). Kuala Lumpur: Dewan Bahasa dan Pustaka, Kementerian Pendidikan Malaysia.

Edward, John. 1995. Multilingualism. New York: Penguin Books.

Fasold, Ralph. 1990. The Sociolinguistics of Language. Cambridge: Basil Blackwell.

Fishman, Joshua A. 1972. The Sociology of Language: An Interdisciplinary Social Science Approach to Language in Society. Massachusetts: Newbury House Publishers.

Hall. Kira \& Bucholtz (ed.) 1995. Articulated Gender: Language and The Socially 
Contructed Self. New York: Spradley, James. 1980. Participant Routledge. Observation. Chicago: Holt, Rinehart

Holmes, Janet. 1995. An Introduction to Sociolinguistics. London: Longman.

Labov, William. 2001. Principles of Linguistic Change (Volume 2: Social Factors). Masschusetts: Blackwell Publisher.

Miles, Matthew B. \& Humerman, A. Michael. 1992. Analisis Data Kualitatif : Buku Sumber tentang Metode-metode Baru. Jakarta: Penerbit Universitas Indonesia.

Moeloeng, Lexy J. 1995. Metodologi Penelitian Kualitatif. Bandung: PT Remaja Ros-dakarya.

Muhadjir, Noeng. 1991. Metodologi Penelitian Kualitatif. Yogyakarta: Rake Sarakin.

Nurkamto, Joko. 2001. "Berbahasa dalam Budaya Konteks Rendah dan Budaya Konteks Tinggi” dalam Linguistik Indonesia: Jurnal Ilmiah Masyarakat Linguistik Indonesia Tahun 19 Nomor 2. Jakarta: MLI dan Yayasan Obor Indonesia.

Poedjosoedarma, Soepomo. 2001. Filsafat Bahasa. Surakarta: Muhammadiyah University Press.

Poedjosoedarma, Soepomo dkk. 1979. Tingkat Tutur Bahasa Jawa. Jakarta: Pusat Pembinaan dan Pengembangan Bahasa, Depdikbud.

Strauss, Anselm \& Corbin, Juliet. 1990. Basics of Qualitative Research: Grounded Theory Prosedures ang Techniques. London: SAGE Publication, International Educational and Professional Publisher.

Trudgill, Peter. 1984. Applied Linguistics. London: Academic Press, Inc. . 1984. On Dialect: Social and Geographical Perspective. New York: Basil Blackwell

Wadhaugh, Ronald. 1988. An Introduction to Sociolinguistics. New York: Basil Blackwell.

Zamzani, Tadkiroatun Musfiroh, dan Prihadi. 2004. Perilaku Verbal Wanita Jawa dalam Interaksi Sosial di Pasar Tradisional di DIY.Yogyakarata: Laporan Penelitian.

Zamzani, Tadkiroatun Musfiroh, dan Prihadi. 2005. "Perilaku Verbal Wanita Jawa dalam Interaksi Sosial di Pasar Tradisional di DIY" dalam Kajian Lingusitik dan Sastra. Volume 17. Surakarta: FKIP Universitas Muhammadiyah Surakarta. 